Jurnal Konstruksi Hukum | ISSN: XXXX | E-ISSN: XXXX Vol. 1, No. 2, Oktober 2020, Hal. 436-442| Available Online at https://www.ejournal.warmadewa.ac.id/index.php/jukonhum DOI: https://doi.org/10.22225/jkh.1.2.2629.436-442

\title{
IMPLEMENTASI PERATURAN DAERAH PROVINSI BALI NOMOR 16 TAHUN 2009 TENTANG RENCANA TATA RUANG WILAYAH PROVINSI DALAM PENGUASAAN DAN PEMANFAATAN WILAYAH PESISIR
}

\author{
Ni Wayan Kertiasih, I Made Suwitra, I Nyoman Sujana \\ Magister Ilmu Hukum Program Pascasarjana Universitas Warmadewa \\ Denpasar Bali, Indonesia. \\ Email: etik_law@yahoo.com
}

\begin{abstract}
Abstrak
Penelitian ini bertujuan untuk menganalisis implementasi Peraturan Daerah Provinsi Bali Nomor 16 Tahun 2009 tentang Rencana Tata Ruang Wilayah Bali dalam penguasaan dan pemanfaatan wilayah pesisir terkait dengan penguasaan dan pemanfaatan kewenangan atas wilayah pesisir serta menganalisis strategi terkait. penguasaan dan pemanfaatan wilayah pesisir. Jenis penelitian yang digunakan berupa penelitian hukum empiris, menggunakan pendekatan pendekatan perundang-undangan, pendekatan analisis konsep hukum, pendekatan antropologis dan pendekatan kasus hukum. Sumber data dalam penelitian ini diperoleh dari data primer dan data sekunder, dikumpulkan dengan tahapan melalui teknik wawancara dan studi keteknikan dan selanjutnya dokumen diolah dan dianalisis secara kualitatif dengan cara sistematis, diklasifikasikan dalam pola dan tema, diklasifikasikan, dihubungkan satu sama lain, untuk memahami pentingnya interpretasi data dalam situasi sosial, dan interpretasi kualitas data secara keseluruhan. Hasil penelitian menunjukkan bahwa kewenangan penguasaan dan pemanfaatan kawasan pesisir setelah berlakunya UU Pemerintah merupakan kewenangan Pemerintah Pusat dan Pemerintah Daerah provinsi, yang untuk pelaksanaannya diberikan pelimpahan kepada Pemerintah Kabupaten / Kota. mengawasi penguasaan dan pemanfaatannya oleh masyarakat setempat. Pengaturan terhadap penguasaan dan pemanfaatan wilayah pesisir Bali harus ditetapkan dengan peraturan daerah, dan sebagaimana diketahui bahwa ketentuan tersebut (pengaturan RZWP3K) masih dalam tahap penyusunan sehingga top rekomendasi pengajuan penguasaan dan pemanfaatan Kawasan pesisir di Provinsi Bali belum diimplementasikan secara efektif.
\end{abstract}

Kata Kunci: Penguasaan; Pemanfaatan Wilayah Pesisir; Tata Ruang

\section{Abstract}

This research aims to analyze the implementation of local regulations regarding Bali province Number of 162009 about Spatial Plan Area of Bali in the mastery and the utilization of the coastal area associated with mastery and authority utilization over the coastal areas as well as analyzing the related strategies of mastery and the utilization of the coastal area. The type of research used in the form of empirical legal research, using the approach the approach to legislation, a legal concept analysis approach, the approach of anthropological approach and the case law. The data source of this research was obtained from primary data and secondary data, collected with the stages through the interview techniques and engineering studies and subsequent documents processed and analyzed qualitatively with systematic way, classified in the pattern and themes, classified, connected between each other, to understand the significance of data interpretation in social situations, and the interpretation of the overall data quality. Research results show that the authority of the mastery and the utilization of the coastal area after the passage of the ACT Government is the authority of the Central Government and the regional Government of the province which is practically given delegates to the district/city Governments overseeing the mastery and its utilization by local community. Setting against the mastery and the utilization of the coastal area of Bali should be established with local regulations, and as it is known that these provisions (RZWP3K settings) are still in the drafting stage so that the top 
recommendations submission of mastery and the utilization of the coastal area in the province of Bali has yet to be implemented effectively.

\section{Keywords: Control; Coastal area utilization; Spatial}

\section{PENDAHULUAN}

Indonesia sebagai Negara yang dikelilingi oleh laut dan garis pantai, sehingga kebijakan penataan pertanahan harus menjadi prioritas pembangunan nasional. Wilayah pesisir dan pulau-pulau kecil di Indonesia merupakan bagian objek kegiatan pengaturan dan penataan yang berpotensi menimbulkan konflik. Untuk menjamin kepastian hukum sebaiknya ditinjau dari aspek penguasaan, pemilikan, penggunaan dan pemanfaatan sehingga perhatian terkait dengan adanya kegiatan percepatan pendaftaran wilayah dirasa perlu untuk segera direalisasikan sebagai wujud dari kedaulatan Negara sesuai hukum pertanahan nasional

Kebijakan pertanahan bagian dari pembangunan di wilayah pesisir yang pelaksanaannya perlu adanya suatu pengaturan yang terarah, berkesinambungan serta berdaya guna dengan konsep pembangunan berkelanjutan berwawasan lingkungan. Pengaturan terkait dengan ketentuan yang mengatur wilayah pesisir diatur pada ketentuan Keputusan Menteri Kelautan dan Perikanan Nomor Kep.10/Men/2003 tentang Pedoman Perencanaan Pengelolaan Pesisir Terpadu, yang menentukan bahwa Wilayah pesisir didefinisikan sebagai wilayah peralihan antara ekosistem darat dan laut yang saling berinteraksi, dimana ke arah laut 12 mil dari garis pantai dan sepertiga dari wilayah laut untuk Kabupaten/Kota dan ke arah darat hingga batas administrasi Kabupaten/Kota.

Ketentuan umum atas penjelasan Peraturan Daerah Provinsi Bali Nomor 16 Tahun 2009 tentang Rencana Tata Ruang Wilayah Provinsi Bali Tahun 2009 - 2029 (selanjutnya disebut Perda RTRWP) menyebutkan bahwa Bali merupakan sebuah pulau kecil yang tidak memiliki sumber daya alam yang melimpah, namun memiliki keunggulan komparatif dari segi keunikan budaya dan keindahan alam, yang merupakan modal dasar bagi Bali dalam menyelenggarakan pembangunan wilayahnya.

Untuk mengatasi permasalahan tata ruang dibutuhkan upaya-upaya pencegahan agar tidak menimbulkan dampak negatif terhadap kelestarian lingkungan, baik fisik maupun sosial-budaya (Harsono, 2002). Salah satu upaya yang harus ditempuh yaitu melakukan kegiatan penataan ruang yang mencakup proses perencanaan, pemanfaatan dan pengendalian pemanfaatan ruang. Pada tahap awal dari proses penataan ruang diperlukan adanya Rencana Tata Ruang Wilayah Provinsi (selanjutnya disingkat RTRWP) sebagai matra ruang dari Rencsana Pembangunan Jangka Panjang Daerah Provinsi Bali.

Ada beberapa penelitian terdahulu terkait penelitian ini yaitu Tahun 2015 Yulianti dkk. (2015) melakukan penelitian mengkaji tentang Urgensi Pengaturan Reklamasi Pantai di Wilayah Pesisir Selatan Madura. Penelitian selanjutnya mengungkapakan bahwa Model pengelolaan wilayah pesisir berbasis masyarakat (community based development) merupakan model yang ideal dan tepat untuk diterapkan dalam rangka mewujudkan kemandirian masyarakat pesisir (Dewi, 2018). Penelitian selanjutnya mengungkapkan bahwa alasan masyarakat Bali menolak reklamasi karena berdampak pada aspek sosial, adat budaya dan lingkungan dan solusi terhadap konflik yang terjadi akibat penolakan reklamasi Teluk Benoa diperlukan kebijakan yang jelas terkait pengaturan tanah hasil reklamasi yang tidak berdampak negatif pada adat budaya dan lingkungan di Bali (Iga, 2019). Penelitian ini didesai dengan tujuan untuk mengetahui kewenangan penguasaan pemanfaatan wilayah pesisir oleh Pemerintah Provinsi Bali dan Strategi penguasaan dan pemanfaatan wilayah pesisir yang berkelanjutan.

\section{METODE PENELITIAN}

Jenis penelitian yang dipakai adalah jenis Penelitian hukum empiris. penelitian ini menggunakan empat jenis pendekatan, yaitu Pendekatan Perundang-undangan (Statute Approach), Pendekatan Analitis Konsep Hukum (Analitical \& Conseptual Approach), Pendekatan Kasus (Case Approach) dan Pendekatan Antropologi Hukum. Sumber data yang digunakan adalah data primer dan data sekunder. data primer yang digunakan adalah data lapangan yang bersumber dari catatan dan pengamatan serta hasil wawancara dengan pihak yang terkait. Sedangkan data sekunder adalah peraturan perundangundangan yang terkait dengan perlindungan dan pengelolaan wialayah pesisir, buku, jurnal makalah yang terkait dengan permasalahan yang diajukan. Selanjutnya teknik analisis data diawali dengan pengolahan data primer selanjutnya dikaitkan dengan data sekunder. Pada tahap pengolahan data ini, 
data yang telah terkumpul selanjutnya dikategorikan dan dikualifikasi berdasarkan permasalahhan yang diajukan selanjutnya dianalisis dengan menggunakan interpretasi hukum, Interpretasi hukum yang digunakan adalah hermeneutika hukum.

\section{PEMBAHASAN}

\section{Kewenangan Penguasaan dan Pemanfaatan Wilayah Pesisir oleh Pemerintah Provinsi Bali}

Pada Pasal 33 ayat (3) UUD RI 1945 telah menggariskan bahwa bumi, air dan kekayaan alam Indonesia dikuasai oleh Negara dan dipergunakan untuk sebesar-besarnya kemakmuran rakyat. Hal ini berlaku pada pengelolaan kawasan pesisir dimana pengelolaan kawasan laut dan pesisir haruslah ditujukan untuk kemakmuran rakyat. Pasal 33 ayat (3) UUD RI 1945 ini memiliki makna penguasaan negara didalamnya sehingga Negara memiliki hak menguasai yang diperoleh secara atributif dari konstitusi. Hak Menguasai Negara ini meliputi seluruh sumber daya alam yang ada di Indonesia baik wilayah darat, laut dan udara. Hak Menguasai Negara ini idealnya tidak dapat dipindahkan kepada pihak lain, tetapi untuk pengelolaannya dapat dilimpahkan kepada daerah maupun kepada pihak ketiga dengan pemberian penguasaan tertentu (Arisaputra, 2015).

Selanjutnya penegasan dari ketentuan Pasal 33 ayat (3) UUD NRI 1945 juga termasuk bagian dari perlindungan yang diberikan keada pengembangan wilayah pesisir yang dimanfaatkan untuk berbagai kepentingan, pengembangan tersebut tentunya membawa perubahan pada ekosistem yang ada. Perubahan-perubahan tersebut membawa pengaruh pada lingkungan yang luas, bahwa semakin tinggi intensitas pembangunan yang dilaksanakan maka semakin tinggi tingkat pemanfaatan sumber daya dan tentunya berdampak pada semakin tinggi pula perubahan yang akan terjadi yaitu penurunan kualitas lingungan seperti pencemaran, kerusakan ekosistem dan overfishing (Sara, 2014).

Untuk mendukung terwujudnya pembangunan wilayah pesisir secara berkelanjutan diarahkan pada pencapaian sebagaimana menurut Effendy (2009) bahwa untuk dapat mewujudkan pembangunan wilayah pesisir secara berkelanjutan ini, maka diperlukan pengelolaan wilayah pesisir secara terpadu (integrated coastal zone management). Pilihan ini didasarkan pada:

(1) wilayah pesisir merupakan multiple use zone di mana terdapat lebih dari dua macam sumber daya alam dan jasa-jasa lingkungan serta terdapat lebih dari 2 (dua) macam pemanfaatan kawasan pesisir;

(2) karakteristik dan dinamika alamiah (the nature) sumber daya pesisir dan lautan yang secara ekologis saling terkait satu sama lain termasuk dengan ekosistem lahan atas;

(3) wilayah pesisir dihuni lebih dari satu kelompok etnis yang memiliki preferensi mata pencaharian yang berbeda

Berdasarkan hasil wawancara pada tanggal 18 Maret 2019 dengan Bapak Ir. I Made Sudarsana, M.Si., selaku Kepala Bidang Kelautan pada Dinas Kelautan dan Perikanan Provinsi Bali menyebutkan bahwa penguasaan dan pemanfaatan wilayah pesisir yang secara ekologi artinya sejauh mana laut menerima dampak dari aktivitas di daratan atau sejauh mana daratan menerima dampat dari air laut, sebagai contoh adalah sejauh mana daratan atau tanaman yang masih terdampak oleh pengaruh dari air laut. Namun penafsiran dalam undang-undang adalah pesisir adalah kearah darat seluas wilayah administratif kecamatan atau untuk ke arah laut sejauh 12 mil. Sehubungan dengan hal tersebut maka perlu dipahami bahwa dasar hukum sebagai pengaturan pada wilayah pesisir adalah UU Pesisir, sedangkan untuk UU No. 26 Tahun 2007 merupakan pengaturan terhadap Rencana Tata Ruang Wilayah.

Sehubungan dengan izin maka harus ada rekomendasi dari dinas kelautan, apabila dilakukan pemanfaatan selain dapat dikategorikan sebagai merusak ekologi wilayah pesisir maka dinas tidak dapat melakuakan upaya mengingat payung hukum seperti RZWP3K belum selesai. Terkait upaya penegakan sepenuhnya diserahkan kepada pihak kepolisian sebagai aparat penegak hukum.

Kegiatan pemanfaatan dan pengelolaan wilayah pesisir dalam lingkup keadilan distributif pemanfaatan dan pengelolaan wilayah pesisir merupakan hak setiap masyarakat termasuk masyarakat pesisir. Keseluruhan kaidah hukum yang diresepsikan dalam bentuk peraturan perundang-undangan dan tentunya mampu meletakkan prinsip-prinsip keadilan di dalamnya, mampu meletakan kesetaraan bagi semua orang, dalam bentuk pemanfaatan wilayah pesisir serta mampu meletakan keseimbangan antara kepentingan pribadi dan kepentingan bersama (Rahmat, 2017).

Berdasarkan hasil wawancara pada tanggal 26 Maret 2019 dengan Bapak I Made Sedana selaku Bendesa Adat Serangan menyebutkan bahwa pengelolaan wilayah pesisir oleh masyarakat sebagai 
bagian dari penunjang komoditas perdagangan dari wisatawan yang datang berkunjung yaitu sepenuhnya dikelola oleh Desa Adat Serangan. Terdapat bagian di beberapa tempat yang ada di Serangan telah dimanfaatkan sebagai tempat untuk menjual souvenir, tourist information, agen dan berbagai wahana water sport untuk wisatawan yang datang ke Desa Serangan dalam bentuk bangunan toko termasuk tempat parkir kapal dari nelayan. Terkait dengan izin penguasaan dan pemanfaatan wilayah pesisir Desa Serangan bahwa pihak Desa Adat Serangan telah berkoordinasi dengan dinasdinas terkait untuk melengkapi dokumen yang dibutuhkan namun hal tersebut tidak dapat diperoleh karena sebagaimana pada Dinas Perikanan dan Kelautan tidak dapat menerbitkan rekomendasi atas hal tersebut atas dasar tidak ada peraturan yang mengatur.

Kewenangan Daerah setelah dengan berlakunya Undang-Undang Nomor 32 Tahun 2004 tentang Pemerintahan Daerah sebagaimana telah diganti dengan UU Pemerintahan Daerah maka tiap-tiap daerah memiliki kewenangan penuh atas daerahnya sendiri. Sebagaimana ketentuan pada Pasal 27 bahwa: Daerah provinsi diberi kewenangan untuk mengelola sumber daya alam di laut yang ada di wilayahnya. Ketentuan pasal ini merupakan penegasan bahwa perubahan berlakunya Undang-Undang Nomor 32 Tahun 2004 tentang Pemerintahan Daerah sebagaimana telah diganti dengan UU Pemerintahan Daerah, juga memuat implikasi terhadap kewenangan pengelolaan laut yang semula terkait dengan zonasi sebagaimana pada Undang-Undang Nomor 32 Tahun 2004 tentang Pemerintahan Daerah ditegaskan bahwa 0-4 mil merupakan kewenangan pemerintah kabupaten/kota dan kewenangan pengelolaan laut 4-12 mil merupakan kewenangan pemerintahan provinsi, kemudian pada UU Pemerintahan Daerah diubah menjadi 0-12 mil, sehingga pengelolaan perairan yang dilakukan sebelumnya oleh pemerintah kabupaten/kota diambil alih oleh pemerintah provinsi.

Pengaturan terkait RZWP3K maka akan berdampak dalam beberapa hal dapat menjadi acuan dalam penyusunan rencana pembangunan jangka panjang daerah (RPJPD) dan rencana pembangunan jangka menengah daerah (RPJMD), sebagai acuan dalam pemanfaatan WP3K, dapat sebagai acuan untuk mewujudkan keseimbangan pembangunan dalam WP3K dan juga dapat sebagai dasar pengendalian pemanfaatan ruang dalam penataan wilayah pesisir dan pulau-pulau kecil. Perencanaan pengelolaan wilayah pesisir berdasarkan ketentuan peraturan perundang-undangan tersebut menegaskan bahwa pengembangan wilayah pesisir yang dimanfaatkan untuk berbagai kepentingan. Kewenangan pemanfaatan dan pengelolaan sebagaimana telah diuraikan diberikan sepenuhnya kepada Pemerintah Daerah Provinsi. Kewenangan pemanfaatan dan pengelolaan dalam sudut pandang teori kewenangan bahwa wewenang pemerintah provinsi adalah wewenang yang diperoleh secara atribusi bersifat asli yang berasal dari peraturan perundang-undangan. Selanjutnya untuk pelaksanaan pemanfaatan wilayah pesisir pemerintah provinsi dapat memberikan wewenang yakni dengan mpendelegasian kepada pemerintah kabupaten/ kota. Pada wewenang yang diperoleh secara delegasi tidak ada penciptaan wewenang, yang ada hanya pelimpahan wewenang dari pejabat yang satu kepada pejabat lainnya. Berdasarkan uraian tersebut maka kewenangan pemanfaatan dan pengelolaan yang sepenuhnya diberikan kepada Pemerintah Daerah Provinsi merupakan kewenangan atribusi yang selanjutnya merupakan dasar hukum yang memuat keharusan kewenangan untuk melaksanakan sesuatu ataupun tidak melaksanakan sesuatu di wilayah pesisir.

Berdasarkan hasil wawancara pada tanggal 18 Maret 2019 dengan Bapak Ir. I Made Sudarsana, M.Si., selaku Kepala Bidang Kelautan pada Dinas Kelautan dan Perikanan Provinsi Bali menyebutkan bahwa kewenangan penguasaan dan pemanfaatan wilayah pesisir di Provinsi Bali sebelumnya perlu juga dipahami bahwa setelah disahkannya UU Pemerintahan Daerah maka daerah kabupaten/kota tidak punya laut, dan terkait dengan laut merupakan kewenangan dari pemerintah provinsi, selanjutnya terhadap penguasaan dan pemanfaatan wilayah pesisir selama ini di Provinsi Bali belum dapat dilakukan secara efektif, mengingat dasar hukum yang digunakan yaitu RZWP3K masih dalam tahapan proses pembuatan. Rancangan peraturan daerah RZWP3K merupakan wadah aspirasi dan kemudian dapat digunakan sebagai payung hukum yang dapat menfasilitasi kepentingan-kepentingan pemanfaatan wilayah pesisir dengan baik, termasuk untuk masyarakat terutama nelayan, juga dapat digunakan sebagai wilayah pariwisata dan kapal nelayan perlu diperhatikan sehingga dapat terintegrasi dengan program pemerintah untuk meningkatkan daya tarik wisata pantai yang bersih dan tertata. Sebagaimana diketahui bahwa kewenangan penguasaan dan pemanfaatan wilayah pesisir harus dilaksanakan melalui pembentukan peraturan daerah, hal tersebut ditegaskan pada ketentuan Pasal 7 dan kemudian dipertegas melalui ketentuan Pasal 9 UU Pesisir. Proses pembentukan RZWP3K ini didasarkan atas kepmen Keputusan Menteri Kelautan dan Perikanan Nomor 23 tahun 2016 tentang 
Mekanisme Pembuatan Rencana Zonasi Wilayah Pesisir dan Pulau-Pulau Kecil, dan dalam proses pembentukan RZWP3K ini tentunya ditujukan untuk menyelamatan sumber daya alam dan keterpaduan yang sifatnya partisipatif, sehingga dalam proses pembentukan aturan tersebut sekedar mengesahkan aturan atas keinginan dari pemerintah.

Prosedur perizinan ditinjau dari 3 elemen utama dari sistem hukum yaitu substansi hukum, struktur hukum dan budaya hukum. Substansi hukum menyangkut aturan (norma) hukum yang berlaku, pada struktur hukum menyangkut aparat penegak hukum dan budaya hukum merupakan hukum yang hidup dan dianut di dalam suatu masyarakat. Substansi hukum menurut paham Negara hukum Indonesia bahwa istilah Negara hukum "rechtsstaat" , "the rule of law" merupakan istilah yang tertera dalam penjelasan UUD NRI 1945 "Negara berdasarkan atas hukum (rechtsstaat), selanjut menjadi Negara hukum pancasila yang mengandung pengertian bahwa Pancasila sebagai rule of law bukan semata-mata sebagai peraturan yang diberlakukan dimasyarakat Indonesia. Hal yang demikian menempatkan sistem dengan idealism tertentu yang bersifat final, dinamis dan selalu mencari tujuan ideal dari sebuah idiologi pancasila (Efendi, 2014).

Substansi hukum sekaligus struktur hukum maka berdasarkan ketentuan pada UU Pesisir bahwa dari pemerintah atas proses pelaksanaan pengelolaan wilayah pesisir, sebagaimana ditegaskan pada ketentuan Pasal 16 UU Pesisir bahwa pengelolaan dan pemanfaatan wilayah perairan pesisir diberikan Supriadi, (2008) dalam bentuk HP-3, selanjutnya terkait dengan kewenangan untuk menerbitkan HP-3 sebagaimana ditegaskan pada ketentuan Pasal 23 ayat (4) bahwa Pemanfaatan Pulau-Pulau Kecil dan perairan disekitarnya sebagaimana dimaksud pada ayat (2) dan memenuhi persyaratan pada ayat (3) wajib mempunyai HP-3 yang diterbitkan oleh pemerintah atau pemerintah daerah sesuai dengan kewenangannya.

Budaya hukum merupakan pemikiran social dan kekuatan social yang menentukan bagaimana hukum digunakan, dihindari atau disalahgunakan. Menurut Suparjati \& Dkk., (2004) menegaskan bahwa mengubah sikap dan prilaku terhadap lingkungan hidup (wilayah pesisir) bukanlah pekerjaan yang mudah, pada dasarnya usaha itu dapat dilakukan dengan tiga yaitu:

a. Instrument pengaturan dan pengawasan dengan mengurangi pilihan pelaku dalam usaha memanfaatkan lingkungan hidup, melalui zonasi atau larangan kegiatan yang merusak lingkungan, pengaturan dan pengawasan, selanjutnya terhadap pelanggaran dapat dikenakan sanksi

b. Instrument ekonomi, untuk mengubah hasil untung relatif terhadap rugi bagi pelaku dengan memberikan insentif-disinsentif ekonomi untuk menghasilkan untung-rugi berupa uang (tangible)

c. Instrument persuasif dengan mendorong masyarakat secara persuasif bukan paksaan dengan tujuan untuk mengubah persepsi hubungan manusia dengan lingkungan kearah memperbesar untung relative terhadap rugi.

Pemanfaatan wilayah peisisr haruslah mengedepankan prinsip-prinsip pembangunan yang berkelanjutan (sustainable development), untuk itu perlu dipahami kehidupan sosial dan budaya masyarakat di wilayah pesisir. Hukum merupakan aktivitas kebudayaan yang berfungsi sebaga sarana pengendalian social (social control), atau sebagai alat untuk menjaga keteraturan soaial (social oreder) (Made, 2009). Pemanfaatan perairan pesisir atau untuk dapat dilakukannya kegiatan penguasaan dan pemanfaatan perairan di wilayah pesisir diwajibkan untuk memiliki izin lokasi dan izin pengelolaan sebagai sarana sebagaimana diamanatkan peraturan perundang-undangan terkait yang dapat dilakukan atau merupakan kewenangan dari Pemerintah Provinsi untuk melaksanakan kegiatan pemberian rekomendasi izin tersebut. Ketentuan Pasal 27 ayat (1) UU Pemerintahan daerah bahwa daerah provinsi diberi kewenangan untuk mengelola sumber daya alam di laut yang ada di wilayahnya.

Berdasarkan hasil wawancara tanggal 18 Maret 2019 dengan Bapak Ir. Made Sudarsana, M.Si. selaku Kepala Bidang Kelautan pada Dinas Kelautan dan Perikanan Provinsi Bali menyatakan terkait dengan pemanfaatan kawasan pesisir tidak akan berdampak negatif apabila rencana pengusahaan perairan pesisir tersebut telah dilengkapi dengan kajian-kajian atas lokasi yang ingin diusahakan baik aspek ekologi, ekonomi, kemasyarakatan termasuk adat istiadat mengingat Provinsi Bali terdapat Desa Adat sebagai wadah kesatuan masyarakat hukum adat di Bali, serta yang paling utama adalah terdapat pihak-pihak yang memiliki peran bertanggung jawab atas dampak yang ditimbulkan dan kajian atas pengambilan bahan dari proses pengusahaan perairan pesisir sesuai dengan peraturan perundangundangan. 


\section{Strategi Penguasaan dan Pemanfaatan Wilayah Pesisir di Provinsi Bali yang Berkelanjutan}

Pengelolaan dan pemanfaatan wilayah pesisir tentunya memerlukan pengaturan secara tepadu agar potensi sumber daya alam yang ada dapat dikembangkan dan dimanfaatkan bagi pembangunan daerah dan nasional secara berkelanjutan. Pengelolaan wilayah pesisir menghendaki adanya pengendalian diri warga masyarakat untuk tidak merusak lingkungan (Fitriansah, 2012). Selanjutnya seiring dengan pelaksanaan otonomi daerah maka wewenang pengelolaan sumber daya alam tersebut khusus pengelolaan terhadap sumber daya kelautan dan perikanan diarahkan kepada daerah provinsi sebagaimana ditegaskan dalam Pasal 27 Ayat (1), Ayat (3), Ayat (4) dan Ayat (5) UU Pemerintah Daerah.

Kebijakan Pemerintah Provinsi Bali terkait penguasaan dan pemanfaatan wilayah pesisir yang berkelanjutan diatur mengenai kewenangan pemerintah daerah untuk mengelola dan memanfaatkan sumber daya pesisir. Wewenang menguasai oleh Negara dapat dimandatkan kepada daerah-daerah sesuai asas otonomi yang dianut dalam sistem pemerintahan. Selain itu pengelolaan sumber daya alam ditujukan untuk kemakmuran dan kesejahteraan rakyat. Bentuk kebijakan yang dilaksanakan secara terpadu oleh pemerintah provinsi Bali melalui koordinasi bersama dengan dinas didangi kelautan dan perikanan maka merujuk pada ketentuan Pasal 10 Ayat (4) UU No. 26 Tahun 2007 dapat memberikan ruang kepada Pemerintah Daerah Kabupaten untuk turut serta melakukan pelaksanaan pemanfaatan ruang dan pengendalian pemanfaatan ruang termasuk wilayah pesisir sebagai bagian dari sistem pengawasan. Peraturan terkait yang juga menegaskan dalam hal pembinaan sebagaimana dinyatakan pada ketentuan Pasal 10 Ayat (6) UU No. 26 Tahun 2007 tersebut bahwa dalam hal pembinaan penataan ruang wilayah pesisir yaitu juga dapat merujuk sebagaimana ditegaskan pada ketentuan Peraturan Pemerintah Nomor 15 Tahun 2010 Tentang Penyelenggaraan Penataan Ruang (selanjutnya disebut PP No. 15 Tahun 2010).

Dalam pemanfaatan wilayah pesisir dapat menimbulkan dampak positif yakni peningkatan kualitas dan nilai ekonomi pesisir, mengurangi laha yang dianggap kurang produktif, sedangakan dampak negatif meliputi dampak fisik yakni pencemaran laut, peningkatan potensi banjir rusaknya habitat lautdan ekosistemnya (Huda, 2013). Hasil wawancara pada tanggal 18 Maret 2019 dengan Bapak Ir. Made Sudarsana, M.Si. selaku kepala bidang kelautan pada dinas kelautan kelautan dan Perikanan Provinsi Bali menyebutkan bahwa terhadap penguasaan dan pemanfaatan wilayah pesisir selama ini di Provinsi Bali diharapkan segera menyelesaikan produk hukum sebagaimana diamanatkan Perda RTRWP dan Keputusan Menteri Kelautan dan Perikanan Nomor 23 Tahun 2016 tentang Mekanisme Pembuatan Rencana Zonasi Wilayah Pesisir dan Pulau-Pulau Kecil.

Kegiatan penguasaan dan pemanfaatan selama tidak mengganggu ekosistem pada wilayah pesisir sebelum disahkannya RZWP3K dalam bentuk peraturan daerah tidak akan dilakukan penertiban kecuali oleh aparat kepolisian bahwa terdapat kegiatan yang dianggap telah melakukan pencemaran atau pengerusakan terhadap ekosistem pada kawasan pesisir. Koordinasi dengan desa dan desa adat merupakan tindakan yang dapat dilakukan untuk memberikan menyuluhan agar turut serta melakukan pengawasan terhadap segala bentuk aktivitas sehingga pencegahan kerusakan ekosistem dapat dicegah ataupun apabila mengetahui telah terjadi maka dapat segera melaporkan kepada pihak kepolisian untuk ditindak lanjuti.

\section{SIMPULAN DAN SARAN \\ Simpulan}

Dari hasil analisis data dapat disimpulkan bahwa Kewenangan penguasaan dan pemanfaatan wilayah pesisir oleh Pemerintah Provinsi Bali bahwa setelah disahkannya Undang-Undang Republik Indonesia Nomor 9 Tahun 2015 tentang perubahan kedua atas Undang-Undang Nomor 23 Tahun 2014 tentang pemerintahan daerah maka daerah kabupaten/kota tidak memiliki laut (wilayah pesisir), diperoleh secara atribusi. Pemanfaatan dan pengelolaan bertujuan mewujudkan kesejahteraan masyarakat termasuk hak masyarakat pesisir, selanjutnya Penguasaan dan pemanfaatan wilayah pesisir di Provinsi Bali yang berkelanjutan bahwa pemerintah Provinsi Bali tidak dapat melakukan penegakan hukum karena dasar hukum yaitu RZWP3K sebagaimana diamanatkan Perda RTRWP dan Keputusan Menteri Kelautan dan Perikanan Nomor 23 Tahun 2016 tentang Mekanisme Pembuatan Rencana Zonasi Wilayah Pesisir dan Pulau-Pulau Kecil. 


\section{Saran}

Adapun yang perlu disarankan oleh peneliti yaitu kepada Dinas perikanan dan kelautan Provinsi Bali selaku fasilitator sekaligus sebagai koordinator yang bertugas menyusun dokumen awal, bersama Dewan Perwakilan Rakyat Daerah Provinsi Bali bersama-sama Gubernur Provinsi Bali serta stakeholder terkait untuk segera melaksanakan proses perumusan kebijakan RZWP3K dengan syarat dan ketentuan yang telah diintruksikan oleh pemerintah pusat dan Penguasaan dan pemanfaatan wilayah pesisir harus dilakukan secara terpadu dengan menggabungkan berbagai perencanaan diberbagai sektor oleh pengambil kebijakan baik pemerintah pusat maupun daerah, sehingga saling terjadi keharmonisan dalam penguasaan, pemanfaatan dalam pengelolaan wilayah pesisir.

\section{DAFTAR PUSTAKA}

Ari Atu Dewi, A. A. I. (2018). Model Pengelolaan Wilayah Pesisir Berbasis Masyarakat: Community Based Development. Jurnal Penelitian Hukum De Jure, 18(2), 163-182.

Arisaputra, M. I. (2015). Reforma Agraria di Indonesia. Sinar Grafika.

Efendi. (2014). Kewenangan Pengelolaan Sumber Daya Alam pada Era Otonomi Khusus di Aceh. Yustisia Jurnal Hukum, 3(2), 108-117.

Effendy, M. (2009). Pengelolaan Wilayah Pesisir Secara Terpadu. Jurnal Kelautan, 2(1), 82-86.

Harsono, B. (2002). Menuju Penyempurnaan Hukum Tanah Nasional. Universitas Trisakti.

Henry Fitriansah. (2012). Keberlanjutan Pengelolaan Lingkungan Pesisir melalui Pemberdayaan Masyarakat di Desa Kwala Lama Kabupaten Serdang Bedagai. Jurnal Pembangunan Wilayah Dan Kota, 8(4), 361-369.

Huda, M. C. (2013). Pengaturan Perizinan Reklamasi Pantai terhadap Perlidungan Lingkngan Hidup. Jurnal Perspektif, 18(2), 126-135.

Made, S. I. (2009). Eksistensi Hak Penguasaan dan Pemilikan atas Tanah Adat di Bali dalam Perspektif Hukum Agraria Nasional. Universitas Brawijaya.

Rahmat, D. (2017). Implementasi Kebijakan Program Bantuan Hukum bagi Masyarakat Tidak Mampu di Kabupaten Kuningan. Univikasi, 4(1), 37-50.

Rina Yulianti, Ikhwan, M., \& Zaman, N. (2015). Urgensi Pengaturan Reklamasi Pantai di Wilayah Pesisir Selatan Madura. Urgensi Pengaturan Reklamasi Pantai, 4(1), 103-121.

Sara, L. (2014). Pengelolaan Wilayah Peissir Gagasan Pemeliharaan Aset wilayah Pesisir dan Solusi Pembangunan Bangsa. Alfabeta.

Suparjati, \& Dkk. (2004). Tata Usaha dan Kearsipan Seri. Kanisius.

Supriadi. (2008). Hukum Lingkungan di Indonesia Sebuah Pengantar. Sinar Grafika. 